\title{
Partial genetic deletion of neuregulin 1 and adolescent stress interact to alter NMDA receptor binding in the medial prefrontal cortex
}

\author{
Tariq W. Chohan ${ }^{1,2}$, An Nguyen ${ }^{1,3}$, Stephanie M. Todd ${ }^{1,2}$, Maxwell R. Bennett ${ }^{1}$, Paul Callaghan ${ }^{1,3}$ and \\ Jonathon C. Arnold ${ }^{1,2 *}$
}

1 The Brain and Mind Research Institute, University of Sydney, Sydney, NSW, Australia

${ }^{2}$ Discipline of Pharmacology, School of Medical Science, University of Sydney, Sydney, NSW, Australia

${ }^{3}$ ANSTO LifeSciences, Australian Nuclear Science and Technology Organisation, Sydney, NSW, Australia

\section{Edited by:}

Nuno Sousa, University of Minho, Portugal

Reviewed by:

Guillaume L. Poirier, University of Massachusetts Medical School, USA Tamas Kozicz, Radboud University Medical Center, Netherlands

*Correspondence:

Jonathon C. Arnold, The Brain and Mind Research Institute, University of Sydney, 100 Mallett Street, Sydney, NSW 2050, Australia e-mail: jonathon.arnold@ sydney.edu.au
Schizophrenia is thought to arise due to a complex interaction between genetic and environmental factors during early neurodevelopment. We have recently shown that partial genetic deletion of the schizophrenia susceptibility gene neuregulin 1 (Nrg1) and adolescent stress interact to disturb sensorimotor gating, neuroendocrine activity and dendritic morphology in mice. Both stress and Nrg1 may have converging effects upon $\mathrm{N}$-methyl-D-aspartate receptors (NMDARs) which are implicated in the pathogenesis of schizophrenia, sensorimotor gating and dendritic spine plasticity. Using an identical repeated restraint stress paradigm to our previous study, here we determined NMDAR binding across various brain regions in adolescent $\mathrm{Nrg} 1$ heterozygous (HET) and wild-type (WT) mice using $\left[{ }^{3} \mathrm{H}\right]$ MK-801 autoradiography. Repeated restraint stress increased NMDAR binding in the ventral part of the lateral septum (LSV) and the dentate gyrus (DG) of the hippocampus irrespective of genotype. Partial genetic deletion of $\mathrm{Nrg} 1$ interacted with adolescent stress to promote an altered pattern of NMDAR binding in the infralimbic (IL) subregion of the medial prefrontal cortex. In the IL, whilst stress tended to increase NMDAR binding in WT mice, it decreased binding in Nrg1 HET mice. However, in the DG, stress selectively increased the expression of NMDAR binding in Nrg1 HET mice but not WT mice. These results demonstrate a Nrg1-stress interaction during adolescence on NMDAR binding in the medial prefrontal cortex.

Keywords: schizophrenia, neuregulin 1, adolescence, stress, NMDA, medial prefrontal cortex, lateral septum hippocampus

\section{INTRODUCTION}

Schizophrenia is thought to arise due to a complex interaction between genetic and environmental factors during critical early periods of neurodevelopment that result in disease onset in late adolescence/early adulthood (Weinberger, 1987; Murray et al., 1991; Lewis and Levitt, 2002; Van Winkel et al., 2008; Jaaro-Peled et al., 2009; Van Winkel et al., 2010; Van Os et al., 2010). Ionotropic N-methyl-D-aspartate receptors (NMDARs) mediate activity-dependent plasticity of glutamatergic synapses (Wenthold et al., 2003; Bennett, 2009) and play a key role in normal brain development through regulation of memory, attention and learning processes (Hudspith, 1997; Lieth et al., 2001; Bennett, 2009; Kantrowitz and Javitt, 2010).

Hypofunction of glutamatergic neurotransmission in the form of abnormal functioning of NMDARs in corticolimbic regions of the brain may explain the symptoms of schizophrenia (Carlsson and Carlsson, 1990; Bennett, 2009). For example, the administration of NMDAR antagonists such as phencyclidine (PCP) to humans induces most of the positive and negative symptom, as well as cognitive impairments observed in schizophrenia patients (Javitt, 1987). Similarly, administration of NMDAR antagonists like MK-801 in rodents, particularly during neurodevelopment, promotes lasting schizophrenia-relevant behavioral phenotypes such as locomotor hyperactivity, prepulse inhibition of startle (PPI) deficits, social withdrawal and cognitive dysfunction (Facchinetti et al., 1993; Sircar, 2000; Wang et al., 2001; Harris et al., 2003; Wiley et al., 2003; Andersen and Pouzet, 2004; Stefani and Moghaddam, 2005; Du Bois et al., 2008). Furthermore, post-mortem schizophrenia brain tissue studies have reported an increased binding of the radiolabelled NMDAR ligand MK-801 in the frontal cortex and caudate-putamen (Kornhuber et al., 1989; Newell et al., 2005). Although, reduced NMDAR sub-unit expression has recently been reported in schizophrenia brains which was accompanied by a reduced concentration of NMDA (Errico et al., 2013).

The neurotrophic factor neuregulin 1 (NRG1), is a widely accepted schizophrenia susceptibility gene which plays a significant role in normal brain maturation by influencing neuronal migration, myelination, and synaptic plasticity (Pearce et al., 1987; McDonald and Johnston, 1990; Stefansson et al., 2002; Harrison and Law, 2006; Mei and Xiong, 2008; Barros et al., 2009; Bennett, 2009, 2011). Interestingly, schizophrenia patients 
show altered expression of both the ErbB family of receptors for NRG1 and NMDARs (Stefansson et al., 2002; Chong et al., 2008; Alaerts et al., 2009; Hatzimanolis et al., 2013). The shared regulation of neuronal plasticity through the Nrg1-ErbB receptor and NMDARs systems has been demonstrated through an interaction in the post synaptic density (PSD) via the anchoring protein PSD-95 (Garcia et al., 2000; Huang et al., 2000; Bao et al., 2004; Murphy and Bielby-Clarke, 2008). Interestingly partial genetic deletion of $\mathrm{Nrg} 1$ hypophosphorylates NR2B subunits of NMDARs (Bjarnadottir et al., 2007) and promotes subtle changes in NMDAR binding in a number of schizophrenia relevant brain regions in adult rodents (Dean et al., 2008; Long et al., 2013; Newell et al., 2013).

Schizophrenia etiology also consists of an environmental component. Early life stress might be the common denominator linking several environmental risk factors including urbanicity, cannabis use, migration, childhood trauma and obstetric complications (Geddes and Lawrie, 1995; Dalman, 2003; Myin-Germeys et al., 2003; Corfas et al., 2004; Glaser et al., 2006; Henquet et al., 2008; Walker et al., 2008; Van Os et al., 2010). Indeed, adolescence is a period of heightened risk to develop schizophrenia (Walker and Bollini, 2002; Costello et al., 2003; Paus et al., 2008). Increased stress reactivity during adolescence coincides with normal maturation of cognitive abilities, and rapid development of the prefrontal cortex (Leussis et al., 2008; Rahdar and Galvan, 2014) and stabilization of the hippocampus (Leussis et al., 2008). Both the prefrontal cortex and hippocampus are vulnerable to the negative effects of stress (Jinks and McGregor, 1997; Sullivan and Gratton, 1999; Buijs and Van Eden, 2000; McEwen, 2007). Moreover, these regions display schizophrenia brain pathology such as a reduced density of dendritic spines, small protrusions which support excitatory synapses in neuronal circuits (Weinberger and Lipska, 1995; Velakoulis et al., 1999; Eichenbaum, 2000; Glantz and Lewis, 2000; Preston et al., 2005; Von Bohlen Und Halbach et al., 2006; Lawrie et al., 2008; Ebdrup et al., 2010). Stress hormone exposure during adolescence in mice, alters the expression of NMDAR subunits in the prefrontal cortex and hippocampus (Lee et al., 2003; Sterlemann et al., 2010; Buret and Van Den Buuse, 2014), regions that regulate cognitive and sensorimotor gating, and are sensitive to stress-induced loss of dendritic spine density and gray matter losses (Kassem et al., 2013). No prior study has directly examined the effects of adolescent restraint stress on $\left[{ }^{3} \mathrm{H}\right] \mathrm{MK}-801$ binding in rodents. In adult rats chronic variable stress increased $\left[{ }^{3} \mathrm{H}\right] \mathrm{MK}-801$ binding in the prefrontal cortex and decreased binding in the hippocampus (Lei and Tejani-Butt, 2010). Given that both neuregulin and stress impact upon NMDARs in their own right, this opens the possibility that neuregulin might confer vulnerability to the effects of stress on NMDAR expression.

Nrg1 confers vulnerability to the effects of environmental challenges of relevance to schizophrenia. Our laboratory has shown that partial genetic deletion of neuregulin 1 increases sensitivity to the neurobehavioral actions of cannabinoids (Boucher et al., 2007a,b, 2011; Long et al., 2010, 2012, 2013; Spencer et al., 2013) and methamphetamine (Spencer et al., 2012), both of which are drugs of abuse known to activate stress systems in the brain including the HPA axis (Gerra et al., 2003; Huizink et al., 2006;
King et al., 2010; Van Leeuwen et al., 2011). We and others have also recently demonstrated that genetic variation in Nrg1 confers vulnerability to the neurobehavioral effects of stress and modifies neuronal signaling pathways sub serving the stress response. For example, rats heterozygous for type II Nrg1 display altered expression of glucocorticoid receptors in the pituitary, hippocampus and paraventricular nucleus of the hypothalamus (Taylor et al., 2010). Partial genetic deletion of Nrg1 conferred vulnerability to the effects of adolescent social defeat stress on spatial working memory function and modulation of inflammatory cytokines in the prefrontal cortex and hippocampus (Desbonnet et al., 2012). We have also recently shown that partial genetic deletion of Nrg1 altered neurobehavioral responses to repeated adolescent restraint stress (Chohan et al., 2014). Repeated adolescent stress selectively impaired the development of normal sensorimotor gating in Nrg1 heterozygous (Nrg1 HET) mice which correlated with a dysregulation in stress-induced corticosterone release. Furthermore, pyramidal neurons in the medial prefrontal cortex of $\mathrm{Nrg} 1 \mathrm{HET}$ mice exposed to repeated adolescent restraint stress had shorter dendritic lengths and complexity, as well as an increased dendritic spine density. Here we hypothesize that repeated restraint stress, coupled with disrupted Nrg1-ErbB4 signaling during adolescence, might interact to alter NMDAR binding in the mouse brain.

\section{METHODS \\ MICE}

Adolescent (PND 35-49) male Nrg1 HET mice (C57BL/6JArc background strain) and wild-type (WT) littermates were used. The mice were bred in our animal house, sourced from a total of 9 litters and intermixed at weaning on postnatal day (PND) 21. Genotypes were determined after weaning at PND 21 as previously described (Karl et al., 2007). The mice were housed (4-5 animals per homecage) in a room on a $12: 12 \mathrm{~h}$ light:dark reverse light schedule with food and water available ad libitum. Animals had access to environmental enrichment including a cardboard toilet roll, igloo, sunflower seeds, tissue paper and running wheels. Environmentally enriched housing is beneficial when exploring gene and environment interactions $(G \times E)$ in mice because it better approximates human cognitive and sensorimotor development than standard housing (Burrows et al., 2011). Nrg1 HET mice were generated by Prof Richard Harvey (Victor Chang Cardiac Research Institute, Sydney) using a targeting vector in which most of exon 11, which encodes the transmembrane domain, was replaced by a neomycin resistance gene cassette (Stefansson et al., 2002). All research and animal care procedures were approved by the University of Sydney's Animal Ethics Committee and were in agreement with the Australian Code of Practice for the Care and use of Animals for Scientific Purposes.

\section{EXPERIMENTAL DESIGN}

Male mice were subjected to $30 \mathrm{~min} /$ day of restraint stress for 14 days from PND 36 to PND 49 as described in our previous study (Chohan et al., 2014). Restraint stress was chosen as it is a well-characterized physical stressor in rodents that activates the HPA axis and increases anxiety-related behavior 
(Eiland and McEwen, 2010; Sutherland et al., 2010; Sutherland and Conti, 2011; Chesworth et al., 2012). Non-stressed animals (WT and $\mathrm{Nrg} 1 \mathrm{HET}$ ) did not receive restraint stress and remained undisturbed in their homecages, similar to prior methods (Eiland and McEwen, 2010; Eiland et al., 2012; Hill et al., 2013; Kwon et al., 2013). Stressed mice were placed in a restraint device (Harvard Apparatus, Holliston, MA, USA), which consisted of a close-ended clear perspex cylinder $(9.5 \times 2.5 \mathrm{~cm})$. Mice were handled daily for 7 days prior to the commencement of experimentation and randomly allocated to 4 experimental groups: (1) WT-no stress (WT NS, $n=6$ ); (2) WT-stress (WT S, $n=7$ ); (3) Nrg1 HET-no stress (Nrg1 HET NS, $n=6$ ), and (4) Nrg1 HETstress (Nrg1 HET S, $n=5$ ). Homecage controls and restraint stressed animals were sacrificed by cervical dislocation immediately following their final $30 \mathrm{~min}$ restraint stress episode on day 14 (PND 49) and their brains were extracted, snap frozen and stored at $-80^{\circ} \mathrm{C}$ prior to sectioning.

\section{NMDA RECEPTOR AUTORADIOGRAPHY}

NMDAR autoradiography was conducted on brains extracted from the same mice that were used to determine corticosterone levels reported previously by our research group (Chohan et al., 2014). In these mice a differential effect of repeated stress was observed between Nrg1 HET and WT mice on plasma corticosterone concentrations. The whole brain was coronally sectioned at $20 \mu \mathrm{m}$ on a cryostat, thaw-mounted onto polysine slides and stored at $-80^{\circ} \mathrm{C}$ until use. Brain regions selected for quantification were identified based on a standard mouse brain atlas (Paxinos, 2004) at bregma levels +1.78 [containing prelimbic (PrL) and infralimbic (IL) cortices); +0.50 (containing anterior cingulate cortex (ACC), rostral caudate-putamen $(\mathrm{rCPu})$, motor cortex (M1-M2), ventrolateral septum (LSV)]; and -1.94 (containing retrosplenial granular cortex (RSG), and subregions of the hippocampus including dentate gyrus (DG), CA1 (cornu ammonis area 1 ) and CA3 (cornu ammonis area 3 ) stratum radiatum layers (Figure 1). Our prior work showed that Nrg1 hypomorphism alone and in combination with stress affected dendritic morphology in the medial prefrontal cortex and hippocampus (Chohan et al., 2014) and so these regions were consequently analyzed for MK-801 binding in the present study. Furthermore, the medial prefrontal cortex and hippocampus are strongly implicated in the neurobiology of schizophrenia and stress (Michelsen et al., 2007; Radley et al., 2008; Alfarez et al., 2009). The caudal ACC region was examined, as it has been shown previously by our group to be affected by stress (Kassem et al., 2013) and is a point of comparison to another MK-801 binding study performed in Nrg1 HET mice (Newell et al., 2013). Further, we examined the LSV at it is thought to mediate stress and anxiety-related behavior (Dielenberg et al., 2001; Sheehan et al., 2004) and was shown to be dysregulated in our prior work on Nrg1-cannabinoid interactions (Boucher et al., 2007b, 2011).

The sections were incubated in $30 \mathrm{mM}$ HEPES buffer $(\mathrm{pH}$ 7.45) containing $23 \mathrm{nM}\left[{ }^{3} \mathrm{H}\right]$ MK-801 (specific activity 27.5 $\mathrm{Ci} / \mathrm{mmol}$, PerkinElmer, USA), $100 \mu \mathrm{M}$ glycine, $100 \mu \mathrm{M} \mathrm{L}$ glutamate and $1 \mathrm{mM}$ EDTA for $2.5 \mathrm{~h}$ at room temperature. Non-specific binding was determined by incubating adjacent sections with $\left[{ }^{3} \mathrm{H}\right]$ MK-801 in the presence of $200 \mu \mathrm{M}$ (ketamine hydrochloride, National Measurement Institute, Sydney, Australia). Following the incubation, the sections were washed twice for $20 \mathrm{~min}$ each at $4^{\circ} \mathrm{C}$ in $30 \mathrm{mM}$ HEPES containing $1 \mathrm{mM}$ EDTA ( $\mathrm{pH}$ 7.45) and rapidly dried under a stream of cool air.

\section{QUANTITATIVE ANALYSIS OF AUTORADIOGRAPHIC IMAGES}

Following the binding assays, all sections were placed on Kodak BioMax MR Film along with a $\left[{ }^{3} \mathrm{H}\right]$ autoradiographic standard (Amersham, UK) for 4 or 6 weeks. Some of the samples from the CA1 region of the hippocampus were re-exposed for 4 weeks due to initial oversaturation of the films, to allow them to fall within the normal pseudolinear response range. Films were developed using Kodak GBX developer/fixer (Sigma-Aldrich, NSW, Australia). Films were scanned using a BioRad GS-800 calibrated densitometer, and quantification of mean density performed in each brain region [average optical density over three adjacent brain sections, for total binding and non-specific binding, using ImageJ (http://rsbweb.nih.gov/ij)]. Using density values for calibrated $\left[{ }^{3} \mathrm{H}\right]$ autoradiographic standards, radioactive concentrations were derived for all density values using a standard curve, and converted into fmol per mg tissue equivalent (fmol/mg). All regions quantified were analyzed blind to treatment group. Specific in vitro binding of $\left[{ }^{3} \mathrm{H}\right] \mathrm{MK}-801$ was calculated by subtraction of non-specific from total binding values. For each brain region, 6 frozen sections ( 3 total binding and 3 non-specific binding were selected per animal. Due to sectioning problems some of the sections were torn and unsuitable for processing. Therefore, for some of the brain regions the final value represents an average from five animals only.

\section{STATISTICAL ANALYSES}

Statistical analyses were performed using SPSS (IBM, IL, USA) or Statview (SAS Institute Inc) software. Statistically significant variation in radioligand binding was identified by Two-Way analysis of variance (ANOVA) with genotype or stress as factors. Planned Bonferroni comparisons were conducted to further analyze differences between experimental groups on all measures using the following four specific comparisons (WT-no stress vs. Nrg1 HET-no stress, WT-stress vs. Nrg1 HET-stress, WT-no stress vs. WT-stress, and Nrg1 HET-no stress vs. Nrg1 HET stress). The results of all analyses were deemed significant at $p<0.05$.

\section{RESULTS}

In all groups, the highest density of specific binding was distinctly observed in the hippocampus (CA1 \& CA3 subregions). Moderately high levels of $\left[{ }^{3} \mathrm{H}\right] \mathrm{MK}-801$ binding were observed in the PrL, IL and anterior cingulate cortices. The rCPu, RSG, M1-M2, DG and LSV subdivisions displayed moderate-low levels of $\left[{ }^{3} \mathrm{H}\right]$ MK-801 binding. Two factor ANOVA revealed a significant genotype by stress interaction $\left(F_{(1,18)}=4.53, p<0.05\right)$ in the IL cortex (Table 1, Figure 2A). A significant effect of stress was found for $\left[{ }^{3} \mathrm{H}\right] \mathrm{MK}-801$ binding in the $\operatorname{LSV}\left(F_{(1,19)}=5.58\right.$, $p<0.05)$ and DG $\left(F_{(1,20)}=15.51, p<0.001\right)$, demonstrating that restraint stress significantly increased NMDAR expression in these regions independent of genotype (Table $\mathbf{1}$ and Figure 2B). Planned Bonferroni comparisons revealed that stressed Nrg1 HET 

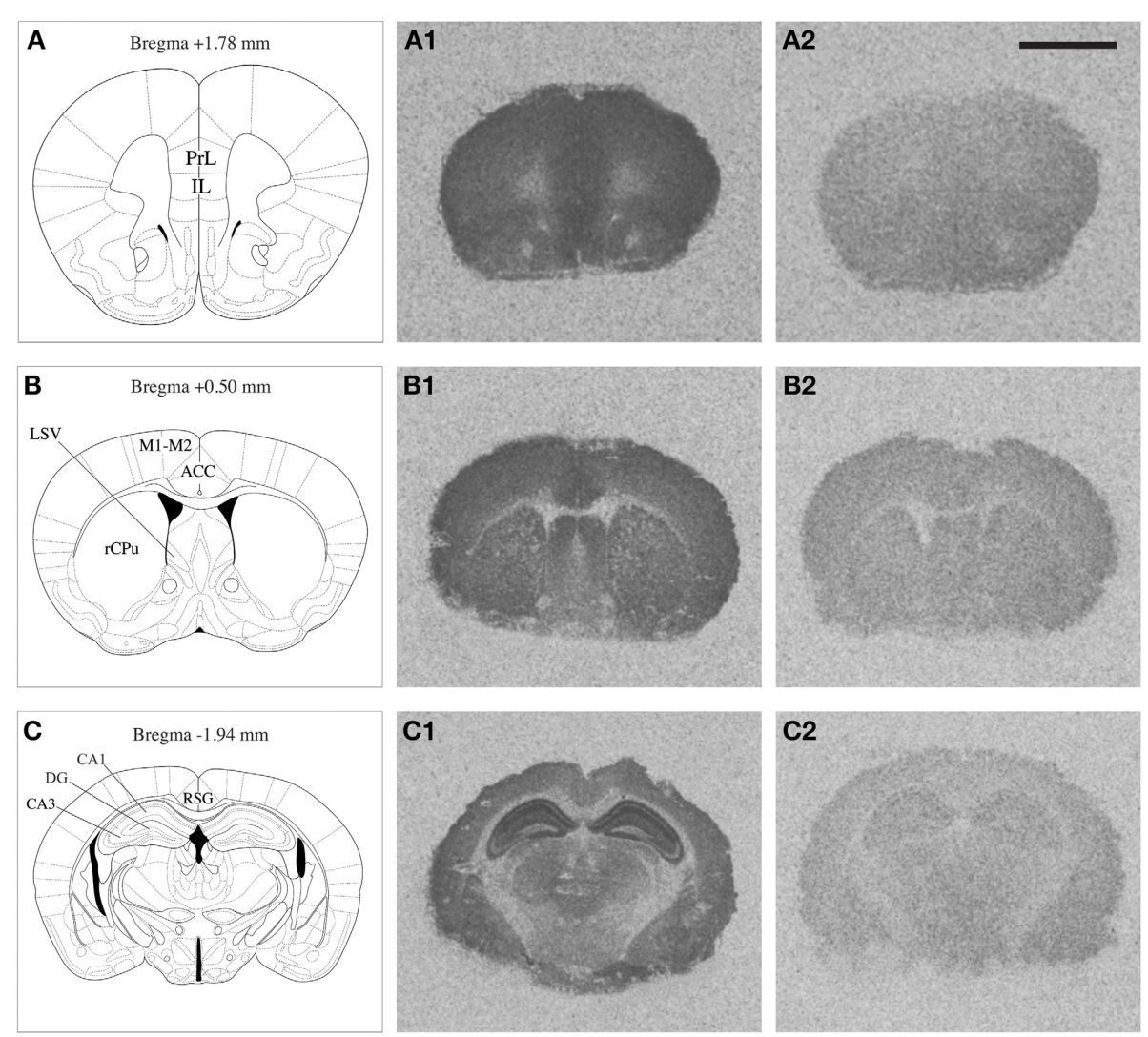

FIGURE 1 | Mouse brain atlas adapted from Paxinos (2004), indicating the brain regions quantified (A,B,C); PrL: prelimbic cortex, IL: infralimbic cortex, rCPu: rostral caudate putamen, M1-M2: motor cortex, ACC: anterior cingulate cortex, LSV: ventrolateral septum, RSG: retrosplenial granular cortex, DG: dentate gyrus, CA1 and CA3 subregions of the hippocampus. Representative autoradiograms of coronal brain sections showing total $\left[{ }^{3} \mathrm{H}\right]$ MK-801 binding $\left(\mathrm{A}_{1}, \mathrm{~B}_{1}, \mathrm{C}_{1}\right)$ and non-specific $\left[{ }^{3} \mathrm{H}\right] \mathrm{MK}-801$ binding $\left(A_{2}, B_{2}, C_{2}\right)$. Scale bar $=2.5 \mathrm{~mm}$. mice exhibited greater MK-801 binding in the DG compared with their non-stressed counterparts $(p<0.01)$. There were no main effects of genotype or stress, or genotype by stress interactions for NMDAR binding in any other brain regions examined (Table 1). No significant NMDAR binding differences between specific experimental groups in the other brain regions were observed $(p>0.05)$.

\section{DISCUSSION}

Here we show that in adolescence partial genetic deletion of $\mathrm{Nrg} 1$ promoted an idiosyncratic change in medial prefrontal cortex NMDAR binding in response to repeated stress. Repeated stress exposure tended to decrease $\left[{ }^{3} \mathrm{H}\right] \mathrm{MK}-801$ binding in $\mathrm{Nrg} 1 \mathrm{HET}$ mice whilst promoting an increase in binding in WT mice in the IL cortex, a subregion of the medial prefrontal cortex. In the DG region of the hippocampus, stress significantly increased NMDAR binding. Interestingly, stressed Nrg1 HET mice displayed significantly higher NMDAR binding than non-stressed Nrg1 HET mice, an effect that was absent in WT mice. In addition, we report for the first time that restraint stress increased $\left[{ }^{3} \mathrm{H}\right] \mathrm{MK}-801$ binding levels in the LSV.

Partial genetic deletion of Nrg1 failed to significantly alter NMDAR binding in the other brain regions examined $(\mathrm{PrL}, \mathrm{rCPu}$,
RSG, ACC, motor cortex \& CA1/CA3 regions of the hippocampus) when measured in late adolescence (PND 49). Prior studies have shown that adult Nrg1 HET mice ( $>$ PND 60) display unaltered $\left[{ }^{3} \mathrm{H}\right]$ MK-801 binding in the cortex, caudate putamen, hippocampus and the septum (Dean et al., 2008; Long et al., 2013). Inconsistent with our present findings in late adolescent mice, adult Nrg1 HET mice exhibited increased NMDAR binding in the ACC and motor cortex compared to WT mice (Newell et al., 2013). The differences observed between the current study and the findings of Newell et al. (2013) may be explained by the different developmental period examined between the studies. As NMDARs undergo significant changes across development (Scheetz and Constantine-Paton, 1994; Cull-Candy et al., 2001; Haberny et al., 2002) and the locomotor hyperactivity phenotype of Nrg1 HET mice develops over time (Karl et al., 2007), it is possible that the effect of partial genetic deletion of $\mathrm{Nrg} 1$ on NMDAR binding might also follow a developmental trajectory and become significant in adulthood.

Here we show for the first time that repeated restraint stress in adolescence increased NMDAR binding in the LSV. The LSV is responsible for promoting active behavioral responses in stressful situations (De Oca and Fanselow, 2004; Sheehan et al., 2004) and its ablation provoked septal rage and exaggerated defensive 


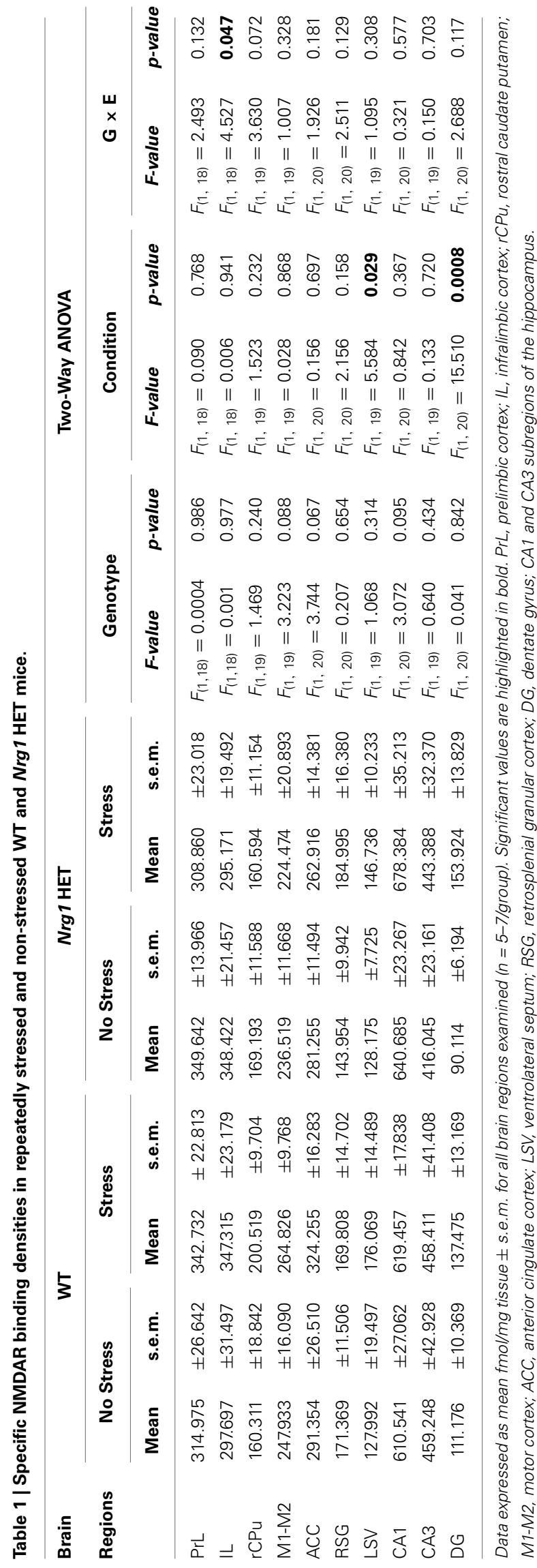

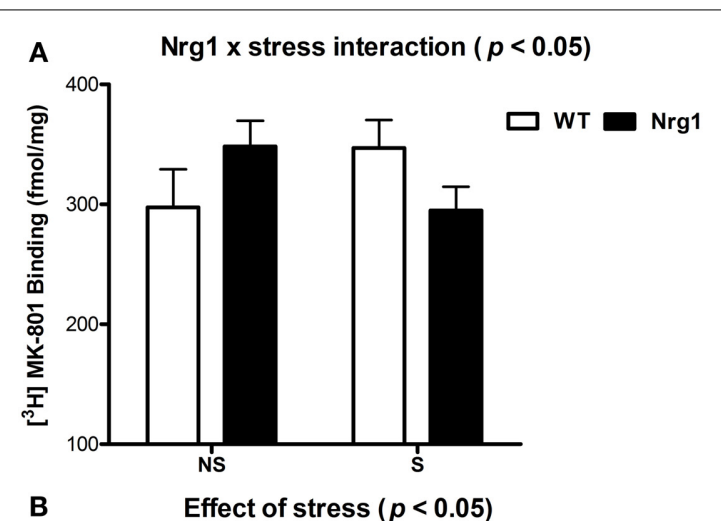
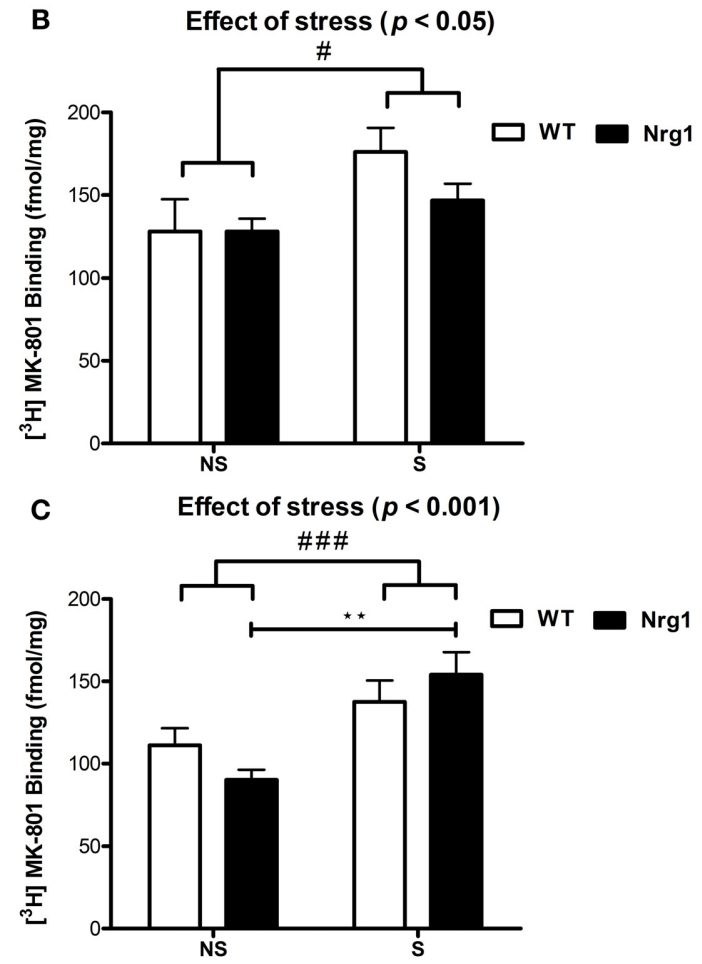

FIGURE $2 \mid\left[{ }^{3} \mathrm{H}\right]$ MK-801 binding to NMDARs (fmol/mg tissue) in (A) infralimbic cortex (IL), (B) ventrolateral septum (LSV) and (C) dentate gyrus (DG) in repeatedly stressed (S) and non-stressed (NS) wild type-like (WT) and $\mathbf{N r g} \mathbf{1}$ HET mice; $\boldsymbol{n}=\mathbf{5 - 7 / g r o u p . ~ D a t a ~ a r e ~ p r e s e n t e d ~}$ as means \pm s.e.m. Significant effects are indicated by $\# p<0.05$ and $\# \# \#<0.001$ (main effects of stress); ${ }^{* *} p<0.01$ [planned Bonferroni comparison, $\mathrm{Nrg} 1 \mathrm{HET}(\mathrm{NS})$ vs. $\mathrm{Nrg} 1 \mathrm{HET}(\mathrm{S})]$.

behaviors (Brady and Nauta, 1953). These findings imply that the integrity of the lateral septum is vital for the inhibition of excessive fear and anxiety. New evidence however indicates that the role of the lateral septum in controlling fear and anxiety is more complex than this, as infusion of CRF type 2 receptor agonists or optogenetic transient activation of CRF type 2 receptors in the lateral septum promoted anxiety-related behaviors (Henry et al., 2006; Anthony et al., 2014). Little research has examined the role of NMDARs in the lateral septum in the control of defensive behaviors. NMDAR knockout mice display reduced aggressive behavior and swim-stress induced Fos expression in the lateral septum than WT mice (Duncan et al., 2009). 
The ability to directly compare studies examining the effects of stress on NMDARs is limited by factors including the diversity of stress paradigms implemented, differences in post-stress washout periods, and the multitude of methods used to analyse NMDAR expression. Most studies have explored the effect of stress on NMDAR subunit protein \& mRNA expression, rather than total NMDAR binding as measured with $\left[{ }^{3} \mathrm{H}\right] \mathrm{MK}-801$ autoradiography (Sterlemann et al., 2010; Buret and Van Den Buuse, 2014). No prior study has directly examined the effects of adolescent restraint stress on $\left[{ }^{3} \mathrm{H}\right] \mathrm{MK}-801$ binding in rodents. In adult rats chronic variable stress increased $\left[{ }^{3} \mathrm{H}\right] \mathrm{MK}-801$ binding in the prefrontal cortex, caudate putamen, nucleus accumbens and basolateral amygdala, while decreasing binding in the hippocampus (Lei and Tejani-Butt, 2010). Here we could only discern measurable effects of stress on the LSV and DG, which might be explained by our use of a relatively mild restraint stress paradigm ( 30 min per day for 14 days). To resolve the effects of stress on NMDAR binding in other brain regions might require a more intense stress regimen like the classic paradigm of $6 \mathrm{~h}$ per day for 21 days that reliably induces retraction of dendrites and loss of gray matter (Radley et al., 2004, 2006, 2008; Magarinos et al., 2011; Kassem et al., 2013). Alternatively, it is possible that earlier application of the stressor (i.e., from PND 28) might have been more effective as recent data suggests that peripubertal stressor exposure (i.e., encompassing the juvenile through to pubertal period, PND 28-42 in rats) is critical to provoking neurobiological changes in stress circuits including increased NMDAR expression (Tzanoulinou et al., 2014).

Using an identical adolescent stress protocol we recently reported that partial genetic deletion of $\mathrm{Nrg} 1$ and repeated stress interacted to offset the normal development of sensorimotor gating and blunted stress-induced corticosterone levels (Chohan et al., 2014). We also provided evidence of abnormal dendritic morphology in the medial prefrontal cortex of Nrg1 HET mice exposed to stress. Specifically, unlike WT mice whose dendritic morphology was unaffected by stress, repeated stress in Nrg1 HET mice reduced the length of dendrites and their complexity, and promoted an increase in dendritic spine density in pyramidal neurons of layers II/III of the anterior cingulate and PrL cortices of the medial prefrontal cortex. Given that Nrgl and stress both influence NMDARs (Garcia et al., 2000; Bjarnadottir et al., 2007; Law et al., 2007; Li et al., 2007; Chong et al., 2008; Bennett, 2009; Cohen et al., 2010; Bennett et al., 2011; Buret and Van Den Buuse, 2014) and that NMDARs regulate the density of dendritic spines (Alvarez et al., 2007; Hayashi-Takagi et al., 2010) we hypothesized that Nrg1 and stress might interact to alter NMDAR binding specifically in the anterior cingulate and PrL cortices.

Therefore, it was surprising to observe in the present study that the Nrg1-stress interaction on NMDAR binding occurred in the IL cortex rather than the PrL cortex. The IL cortex shares reciprocal connections with the PrL cortex (Gabbott et al., 2003, 2005; Jones et al., 2005; Hoover and Vertes, 2007; Gutman et al., 2012) and the IL and PrL regions of the medial prefrontal cortex cooperate to produce an integrated response to stress (McDougall et al., 2004). Therefore, it is possible then that the changes in dendritic morphology in the anterior cingulate and PrL cortices in our previous study (Chohan et al., 2014) may be a cause or consequence of the Nrg1-stress interaction on NMDAR binding in the IL cortex we observed here. Indeed, perturbation of activity in the IL has flow on effects on the PrL cortex, as activation of IL cortex output via optical stimulation in adult rats inhibits PrL pyramidal neurons (Ji and Neugebauer, 2012). Here, there was a tendency toward reduced $\left[{ }^{3} \mathrm{H}\right] \mathrm{MK}-801$ binding in the medial prefrontal cortex of Nrg1 HET mice which accords with the general view of NMDAR hypofunction in schizophrenia as well as research showing that NMDAR expression is reduced in the schizophrenia brain (Errico et al., 2013). Although, this contradicts studies that report $\left[{ }^{3} \mathrm{H}\right]$ increased MK-801 binding in post-mortem schizophrenia brains (Kornhuber et al., 1989; Newell et al., 2005).

Here we report that repeated stress-induced increased NMDAR binding in the DG in Nrg1 HET mice but not in WT mice, which provides some additional support for Nrgl HET mice being more sensitive to the effects of stress on NMDAR binding. However, this must be interpreted cautiously in the absence of an overall interaction between Nrgl genotype and stress condition. The DG plays an important role in memory and sensorimotor gating function (Reul et al., 2009; Guo et al., 2013), thus the stress induced increase in NMDAR binding specifically in Nrg1 HET mice observed here may partially explain the spatial memory and PPI deficits observed previously in these mice following adolescent stress (Desbonnet et al., 2012; Chohan et al., 2014). Juvenile stress decreases expression of type III Nrg1 in the hippocampus (Brydges et al., 2014), so it is possible that the effects of stress on an already depleted Nrg1 level in hypomorphic mice is sufficient to then increase $\left[{ }^{3} \mathrm{H}\right] \mathrm{MK}-801$ binding. Why the DG but not the CA1 or CA3 region is selectively vulnerable to this effect is unclear. It might be partially explained by the DG expressing relatively lower levels of NRG1 than other hippocampal subfields (Law et al., 2004). The mechanisms responsible for the effect of stress on $\left[{ }^{3} \mathrm{H}\right] \mathrm{MK}-801$ binding in Nrg1 HET mice will need to be specifically addressed in future research including studies which directly examine the expression, internalization and phosphorylation status of NMDAR, and also whether this effect can be magnified by a more intense stress protocol.

Our findings further reinforce research showing that variation in $\mathrm{Nrgl}$ confers vulnerability to the effects of stress. Human studies have shown that a NRG1 polymorphism interacted with psychosocial stress to effect reactivity to expressed emotions in schizophrenia patients (Keri et al., 2009) and that polymorphic variation in NRG1 interacts with job strain to increase the risk of heart disease (Hintsanen et al., 2007). Reduced type II $\mathrm{Nrg} 1$ expression in rats induced increased baseline corticosterone levels, a disruption in recovery of stress-induced plasma corticosterone concentrations, as well as elevated levels of glucocorticoid receptors in the hippocampus, paraventricular nucleus of the hypothalamus and pituitary gland (Taylor et al., 2010). Further, complex gender specific interactions of type II Nrg1 genotype and adolescent chronic variable stress were reported on anxietyrelated behavior and cued fear conditioning (Taylor et al., 2012). Stress-induced increase in corticosterone was more pronounced in Nrg1 HET mice than WT mice at the younger (3-4 months) but not the older age group (6-7 months) (Chesworth et al., 2012), highlighting the developmental effect of stress and Nrg1 
hypomorphism on the HPA axis. Adolescent social defeat stress has also been shown to selectively impair spatial memory and decrease expression of the inflammatory cytokine interleukin $1 \beta$ in the prefrontal cortex of Nrg1 HET mice, but not WT mice (Desbonnet et al., 2012). The latter finding might be related to the present finding of partial genetic deletion of $\mathrm{Nrgl}$ promoting a unique stress-induced downregulation of NMDAR binding in the prefrontal cortex, as interleukin $1 \beta$ (IL $1 \beta$ ) has been shown to potentiate NMDA function and reduce the density of synaptic spines (Viviani et al., 2003, 2006). Further, the effects of IL $1 \beta$ are mediated by interleukin receptor 1 (ILR1) which appear to interact with NR2B subunits of the NMDAR in the postsynaptic density (Gardoni et al., 2011; Viviani et al., 2013).

\section{ACKNOWLEDGMENTS}

This work was supported by a University of Sydney Bridging Grant to JCA.

\section{REFERENCES}

Alaerts, M., Ceulemans, S., Forero, D., Moens, L. N., De Zutter, S., Heyrman, L., et al. (2009). Support for NRG1 as a susceptibility factor for schizophrenia in a northern Swedish isolated population. Arch. Gen. Psychiatry 66, 828-837. doi: 10.1001/archgenpsychiatry.2009.82

Alfarez, D. N., De Simoni, A., Velzing, E. H., Bracey, E., Joels, M., Edwards, F. A., et al. (2009). Corticosterone reduces dendritic complexity in developing hippocampal CA1 neurons. Hippocampus 19, 828-836. doi: 10.1002/hipo. 20566

Alvarez, V. A., Ridenour, D. A., and Sabatini, B. L. (2007). Distinct structural and ionotropic roles of NMDA receptors in controlling spine and synapse stability. J. Neurosci. 27, 7365-7376. doi: 10.1523/JNEUROSCI.0956-07.2007

Andersen, J. D., and Pouzet, B. (2004). Spatial memory deficits induced by perinatal treatment of rats with PCP and reversal effect of D-serine. Neuropsychopharmacology 29, 1080-1090. doi: 10.1038/sj.npp.1300394

Anthony, T. E., Dee, N., Bernard, A., Lerchner, W., Heintz, N., and Anderson, D. J. (2014). Control of stress-induced persistent anxiety by an extra-amygdala septohypothalamic circuit. Cell 156, 522-536. doi: 10.1016/j.cell.2013.12.040

Bao, J., Lin, H., Ouyang, Y., Lei, D., Osman, A., Kim, T. W., et al. (2004). Activitydependent transcription regulation of PSD-95 by neuregulin-1 and Eos. Nat. Neurosci. 7, 1250-1258. doi: 10.1038/nn1342

Barros, C. S., Calabrese, B., Chamero, P., Roberts, A. J., Korzus, E., Lloyd, K., et al. (2009). Impaired maturation of dendritic spines without disorganization of cortical cell layers in mice lacking NRG1/ErbB signaling in the central nervous system. Proc. Natl. Acad. Sci. U.S.A. 106, 4507-4512. doi: 10.1073/pnas.0900355106

Bennett, M. (2009). Positive and negative symptoms in schizophrenia: the NMDA receptor hypofunction hypothesis, neuregulin/ErbB4 and synapse regression. Aust. N.Z. J. Psychiatry 43, 711-721. doi: 10.1080/00048670903001943

Bennett, M. R. (2011). Schizophrenia: susceptibility genes, dendritic-spine pathology and gray matter loss. Prog. Neurobiol. 95, 275-300. doi: 10.1016/j.pneurobio.2011.08.003

Bennett, M. R., Farnell, L., and Gibson, W. G. (2011). A model of neuregulin control of NMDA receptors on synaptic spines. Bull. Math. Biol. 74, 717-735. doi: 10.1007/s11538-011-9706-9

Bjarnadottir, M., Misner, D. L., Haverfield-Gross, S., Bruun, S., Helgason, V. G., Stefansson, H., et al. (2007). Neuregulin1 (NRG1) signaling through Fyn modulates NMDA receptor phosphorylation: differential synaptic function in NRG1+/- knock-outs compared with wild-type mice. J. Neurosci. 27, 4519-4529. doi: 10.1523/JNEUROSCI.4314-06.2007

Boucher, A. A., Arnold, J. C., Duffy, L., Schofield, P. R., Micheau, J., and Karl, T. (2007a). Heterozygous neuregulin 1 mice are more sensitive to the behavioural effects of Delta9-tetrahydrocannabinol. Psychopharmacology (Berl) 192, 325-336. doi: 10.1007/s00213-007-0721-3

Boucher, A. A., Hunt, G. E., Karl, T., Micheau, J., McGregor, I. S., and Arnold, J. C. (2007b). Heterozygous neuregulin 1 mice display greater baseline and Delta(9)-tetrahydrocannabinol-induced c-Fos expression. Neuroscience 149, 861-870. doi: 10.1016/j.neuroscience. 2007.08.020

Boucher, A. A., Hunt, G. E., Micheau, J., Huang, X., McGregor, I. S., Karl, T., et al. (2011). The schizophrenia susceptibility gene neuregulin 1 modulates tolerance to the effects of cannabinoids. Int. J. Neuropsychopharmacol. 14, 631-643. doi: $10.1017 /$ S146114571000091X

Brady, J. V., and Nauta, W. J. (1953). Subcortical mechanisms in emotional behavior: affective changes following septal forebrain lesions in the albino rat. J. Comp. Physiol. Psychol. 46, 339-346. doi: 10.1037/h0059531

Brydges, N. M., Seckl, J., Torrance, H. S., Holmes, M. C., Evans, K. L., and Hall, J. (2014). Juvenile stress produces long-lasting changes in hippocampal DISC1, GSK3ss and NRG1 expression. Mol. Psychiatry 19, 854-855. doi: $10.1038 / \mathrm{mp} .2013 .193$

Buijs, R. M., and Van Eden, C. G. (2000). The integration of stress by the hypothalamus, amygdala and prefrontal cortex: balance between the autonomic nervous system and the neuroendocrine system. Prog. Brain Res. 126, 117-132. doi: 10.1016/S0079-6123(00)26011-1

Buret, L., and Van Den Buuse, M. (2014). Corticosterone treatment during adolescence induces down-regulation of reelin and NMDA receptor subunit GLUN2C expression only in male mice: implications for schizophrenia. Int. J. Neuropsychopharmacol. 17, 1221-1232. doi: 10.1017/S1461145714 000121

Burrows, E. L., McOmish, C. E., and Hannan, A. J. (2011). Gene-environment interactions and construct validity in preclinical models of psychiatric disorders. Prog. Neuropsychopharmacol. Biol. Psychiatry 35, 1376-1382. doi: 10.1016/j.pnpbp.2010.12.011

Carlsson, M., and Carlsson, A. (1990). Schizophrenia: a subcortical neurotransmitter imbalance syndrome? Schizophr. Bull. 16, 425-432.

Chesworth, R., Yulyaningsih, E., Cappas, E., Arnold, J., Sainsbury, A., and Karl, T. (2012). The response of neuregulin 1 mutant mice to acute restraint stress. Neurosci. Lett. 515, 82-86. doi: 10.1016/j.neulet.2012.03.024

Chohan, T. W., Boucher, A. A., Spencer, J. R., Kassem, M. S., Hamdi, A. A., Karl, T., et al. (2014). Partial genetic deletion of neuregulin 1 modulates the effects of stress on sensorimotor gating, dendritic morphology, and hpa axis activity in adolescent mice. Schizophr. Bull. doi: 10.1093/schbul/sbt193. [Epub ahead of print].

Chong, V. Z., Thompson, M., Beltaifa, S., Webster, M. J., Law, A. J., and Weickert, C. S. (2008). Elevated neuregulin-1 and ErbB4 protein in the prefrontal cortex of schizophrenic patients. Schizophr. Res. 100, 270-280. doi: 10.1016/j.schres.2007.12.474

Cohen, J. W., Louneva, N., Han, L. Y., Hodes, G., Wilson, R. S., Bennett, D. A., et al. (2010). Chronic corticosterone exposure alters postsynaptic protein levels of PSD-95, NR1, and synaptopodin in the mouse brain. Synapse 65, 763-770. doi: 10.1002/syn.20900

Corfas, G., Roy, K., and Buxbaum, J. D. (2004). Neuregulin 1-erbB signaling and the molecular/cellular basis of schizophrenia. Nat. Neurosci. 7, 575-580. doi: $10.1038 / \mathrm{nn} 1258$

Costello, E. J., Mustillo, S., Erkanli, A., Keeler, G., and Angold, A. (2003). Prevalence and development of psychiatric disorders in childhood and adolescence. Arch. Gen. Psychiatry 60, 837-844. doi: 10.1001/archpsyc.60.8.837

Cull-Candy, S., Brickley, S., and Farrant, M. (2001). NMDA receptor subunits: diversity, development and disease. Curr. Opin. Neurobiol. 11, 327-335. doi: 10.1016/S0959-4388(00)00215-4

Dalman, C. (2003). [Obstetric complications and risk of schizophrenia. An association appears undisputed, yet mechanisms are still unknown]. Lakartidningen 100, 1974-1979.

Dean, B., Karl, T., Pavey, G., Boer, S., Duffy, L., and Scarr, E. (2008). Increased levels of serotonin 2A receptors and serotonin transporter in the CNS of neuregulin 1 hypomorphic/mutant mice. Schizophr. Res. 99, 341-349. doi: 10.1016/j.schres.2007.10.013

De Oca, B. M., and Fanselow, M. S. (2004). Amygdala and periaqueductal gray lesions only partially attenuate unconditional defensive responses in rats exposed to a cat. Integr. Physiol. Behav. Sci. 39, 318-333. doi: 10.1007/BF02734170

Desbonnet, L., O’tuathaigh, C., Clarke, G., O’leary, C., Petit, E., Clarke, N., et al. (2012). Phenotypic effects of repeated psychosocial stress during adolescence in mice mutant for the schizophrenia risk gene neuregulin-1: a putative model of gene $\mathrm{x}$ environment interaction. Brain Behav. Immun. 26, 660-671. doi: 10.1016/j.bbi.2012.02.010 
Dielenberg, R. A., Hunt, G. E., and McGregor, I. S. (2001). "When a rat smells a cat": the distribution of Fos immunoreactivity in rat brain following exposure to a predatory odor. Neuroscience 104, 1085-1097. doi: 10.1016/S03064522(01)00150-6

Du Bois, T. M., Huang, X. F., and Deng, C. (2008). Perinatal administration of PCP alters adult behaviour in female Sprague-Dawley rats. Behav. Brain Res. 188, 416-419. doi: 10.1016/j.bbr.2007.11.017

Duncan, G. E., Inada, K., Farrington, J. S., Koller, B. H., and Moy, S. S. (2009). Neural activation deficits in a mouse genetic model of NMDA receptor hypofunction in tests of social aggression and swim stress. Brain Res. 1265, 186-195. doi: 10.1016/j.brainres.2009.02.002

Ebdrup, B. H., Glenthoj, B., Rasmussen, H., Aggernaes, B., Langkilde, A. R., Paulson, O. B., et al. (2010). Hippocampal and caudate volume reductions in antipsychotic-naive first-episode schizophrenia. J. Psychiatry Neurosci. 35, 95-104. doi: 10.1503/jpn.090049

Eichenbaum, H. (2000). A cortical-hippocampal system for declarative memory. Nat. Rev. Neurosci. 1, 41-50. doi: 10.1038/35036213

Eiland, L., and McEwen, B. S. (2010). Early life stress followed by subsequent adult chronic stress potentiates anxiety and blunts hippocampal structural remodeling. Hippocampus 22, 82-91. doi: 10.1002/hipo.20862

Eiland, L., Ramroop, J., Hill, M. N., Manley, J., and McEwen, B. S. (2012). Chronic juvenile stress produces corticolimbic dendritic architectural remodeling and modulates emotional behavior in male and female rats. Psychoneuroendocrinology 37, 39-47. doi: 10.1016/j.psyneuen.2011.04.015

Errico, F., Napolitano, F., Squillace, M., Vitucci, D., Blasi, G., De Bartolomeis, A., et al. (2013). Decreased levels of D-aspartate and NMDA in the prefrontal cortex and striatum of patients with schizophrenia. J. Psychiatr. Res. 47, 1432-1437. doi: 10.1016/j.jpsychires.2013.06.013

Facchinetti, F., Ciani, E., Dall'olio, R., Virgili, M., Contestabile, A., and Fonnum, F. (1993). Structural, neurochemical and behavioural consequences of neonatal blockade of NMDA receptor through chronic treatment with CGP 39551 or MK-801. Brain Res. Dev. Brain Res. 74, 219-224.

Gabbott, P. L., Warner, T. A., Jays, P. R., and Bacon, S. J. (2003). Areal and synaptic interconnectivity of prelimbic (area 32), infralimbic (area 25) and insular cortices in the rat. Brain Res. 993, 59-71. doi: 10.1016/j.brainres.2003.08.056

Gabbott, P. L., Warner, T. A., Jays, P. R., Salway, P., and Busby, S. J. (2005). Prefrontal cortex in the rat: projections to subcortical autonomic, motor, and limbic centers. J. Comp. Neurol. 492, 145-177. doi: 10.1002/cne.20738

Garcia, R. A., Vasudevan, K., and Buonanno, A. (2000). The neuregulin receptor ErbB-4 interacts with PDZ-containing proteins at neuronal synapses. Proc. Natl. Acad. Sci. U.S.A. 97, 3596-3601. doi: 10.1073/pnas.97.7.3596

Gardoni, F., Boraso, M., Zianni, E., Corsini, E., Galli, C. L., Cattabeni, F, et al. (2011). Distribution of interleukin-1 receptor complex at the synaptic membrane driven by interleukin-1beta and NMDA stimulation. J. Neuroinflammation 8:14. doi: 10.1186/1742-2094-8-14

Geddes, J. R., and Lawrie, S. M. (1995). Obstetric complications and schizophrenia: a meta-analysis. Br. J. Psychiatry 167, 786-793. doi: 10.1192/bjp.167.6.786

Gerra, G., Bassignana, S., Zaimovic, A., Moi, G., Bussandri, M., Caccavari, R., et al. (2003). Hypothalamic-pituitary-adrenal axis responses to stress in subjects with 3,4-methylenedioxy-methamphetamine ("ecstasy") use history: correlation with dopamine receptor sensitivity. Psychiatry Res. 120, 115-124. doi: 10.1016/S0165-1781(03)00175-6

Glantz, L. A., and Lewis, D. A. (2000). Decreased dendritic spine density on prefrontal cortical pyramidal neurons in schizophrenia. Arch. Gen. Psychiatry 57, 65-73. doi: 10.1001/archpsyc.57.1.65

Glaser, J. P., Van Os, J., Portegijs, P. J., and Myin-Germeys, I. (2006). Childhood trauma and emotional reactivity to daily life stress in adult frequent attenders of general practitioners. J. Psychosom. Res. 61, 229-236. doi: 10.1016/j.jpsychores.2006.04.014

Guo, N., Yoshizaki, K., Kimura, R., Suto, F., Yanagawa, Y., and Osumi, N. (2013). A sensitive period for GABAergic interneurons in the dentate gyrus in modulating sensorimotor gating. J. Neurosci. 33, 6691-6704. doi: 10.1523/JNEUROSCI.0032-12.2013

Gutman, D. A., Keifer, O. P. Jr., Magnuson, M. E., Choi, D. C., Majeed, W., Keilholz, S., et al. (2012). A DTI tractography analysis of infralimbic and prelimbic connectivity in the mouse using high-throughput MRI. Neuroimage 63, 800-811. doi: 10.1016/j.neuroimage.2012.07.014

Haberny, K. A., Paule, M. G., Scallet, A. C., Sistare, F. D., Lester, D. S., Hanig, J. P., et al. (2002). Ontogeny of the N-methyl-D-aspartate (NMDA) receptor system and susceptibility to neurotoxicity. Toxicol. Sci. 68, 9-17. doi: 10.1093/toxsci/68.1.9

Harris, L. W., Sharp, T., Gartlon, J., Jones, D. N., and Harrison, P. J. (2003). Longterm behavioural, molecular and morphological effects of neonatal NMDA receptor antagonism. Eur. J. Neurosci. 18, 1706-1710. doi: 10.1046/j.14609568.2003.02902.x

Harrison, P. J., and Law, A. J. (2006). Neuregulin 1 and schizophrenia: genetics, gene expression, and neurobiology. Biol. Psychiatry 60, 132-140. doi: 10.1016/j.biopsych.2005.11.002

Hatzimanolis, A., McGrath, J. A., Wang, R., Li, T., Wong, P. C., Nestadt, G., et al. (2013). Multiple variants aggregate in the neuregulin signaling pathway in a subset of schizophrenia patients. Transl. Psychiatry 3:e264. doi: 10.1038/tp. 2013.33

Hayashi-Takagi, A., Takaki, M., Graziane, N., Seshadri, S., Murdoch, H., Dunlop, A. J., et al. (2010). Disrupted-in-Schizophrenia 1 (DISC1) regulates spines of the glutamate synapse via Rac1. Nat. Neurosci. 13, 327-332. doi: 10.1038/nn.2487

Henquet, C., Di Forti, M., Morrison, P., Kuepper, R., and Murray, R. M. (2008). Gene-environment interplay between cannabis and psychosis. Schizophr. Bull. 34, 1111-1121. doi: 10.1093/schbul/sbn108

Henry, B., Vale, W., and Markou, A. (2006). The effect of lateral septum corticotropin-releasing factor receptor 2 activation on anxiety is modulated by stress. J. Neurosci. 26, 9142-9152. doi: 10.1523/JNEUROSCI.1494-06.2006

Hill, M. N., Kumar, S. A., Filipski, S. B., Iverson, M., Stuhr, K. L., Keith, J. M., et al. (2013). Disruption of fatty acid amide hydrolase activity prevents the effects of chronic stress on anxiety and amygdalar microstructure. Mol. Psychiatry 18, 1125-1135. doi: 10.1038/mp.2012.90

Hintsanen, M., Elovainio, M., Puttonen, S., Kivimaki, M., Raitakari, O. T., Lehtimaki, T., et al. (2007). Neuregulin-1 genotype moderates the association between job strain and early atherosclerosis in young men. Ann. Behav. Med. 33, 148-155. doi: 10.1007/BF02879896

Hoover, W. B., and Vertes, R. P. (2007). Anatomical analysis of afferent projections to the medial prefrontal cortex in the rat. Brain Struct. Funct. 212, 149-179. doi: 10.1007/s00429-007-0150-4

Huang, Y. Z., Won, S., Ali, D. W., Wang, Q., Tanowitz, M., Du, Q. S., et al. (2000). Regulation of neuregulin signaling by PSD-95 interacting with ErbB4 at CNS synapses. Neuron 26, 443-455. doi: 10.1016/S0896-6273(00)81176-9

Hudspith, M. J. (1997). Glutamate: a role in normal brain function, anaesthesia, analgesia and CNS injury. Br. J. Anaesth. 78, 731-747. doi: 10.1093/bja/78.6.731

Huizink, A. C., Ferdinand, R. F., Ormel, J., and Verhulst, F. C. (2006). Hypothalamic-pituitary-adrenal axis activity and early onset of cannabis use. Addiction 101, 1581-1588. doi: 10.1111/j.1360-0443.2006.01570.x

Jaaro-Peled, H., Hayashi-Takagi, A., Seshadri, S., Kamiya, A., Brandon, N. J., and Sawa, A. (2009). Neurodevelopmental mechanisms of schizophrenia: understanding disturbed postnatal brain maturation through neuregulin-1-ErbB4 and DISC1. Trends Neurosci. 32, 485-495. doi: 10.1016/j.tins.2009.05.007

Javitt, D. C. (1987). Negative schizophrenic symptomatology and the PCP (phencyclidine) model of schizophrenia. Hillside J. Clin. Psychiatry 9, 12-35.

Ji, G., and Neugebauer, V. (2012). Modulation of medial prefrontal cortical activity using in vivo recordings and optogenetics. Mol. Brain 5, 36. doi: 10.1186/17566606-5-36

Jinks, A. L., and McGregor, I. S. (1997). Modulation of anxiety-related behaviours following lesions of the prelimbic or infralimbic cortex in the rat. Brain Res. 772, $181-190$.

Jones, B. F., Groenewegen, H. J., and Witter, M. P. (2005). Intrinsic connections of the cingulate cortex in the rat suggest the existence of multiple functionally segregated networks. Neuroscience 133, 193-207. doi: 10.1016/j.neuroscience.2005.01.063

Kantrowitz, J. T., and Javitt, D. C. (2010). N-methyl-d-aspartate (NMDA) receptor dysfunction or dysregulation: the final common pathway on the road to schizophrenia? Brain Res. Bull. 83, 108-121. doi: 10.1016/j.brainresbull.2010.04.006

Karl, T., Duffy, L., Scimone, A., Harvey, R. P., and Schofield, P. R. (2007). Altered motor activity, exploration and anxiety in heterozygous neuregulin 1 mutant mice: implications for understanding schizophrenia. Genes Brain Behav. 6, 677-687. doi: 10.1111/j.1601-183X.2006.00298.x

Kassem, M. S., Lagopoulos, J., Stait-Gardner, T., Price, W. S., Chohan, T. W., Arnold, J. C., et al. (2013). Stress-induced grey matter loss determined by MRI is primarily due to loss of dendrites and their synapses. Mol. Neurobiol. 47, 645-661. doi: 10.1007/s12035-012-8365-7 
Keri, S., Kiss, I., Seres, I., and Kelemen, O. (2009). A polymorphism of the neuregulin 1 gene (SNP8NRG243177/rs6994992) affects reactivity to expressed emotion in schizophrenia. Am. J. Med. Genet. B Neuropsychiatr. Genet. 150B, 418-420. doi: 10.1002/ajmg.b.30812

King, G., Alicata, D., Cloak, C., and Chang, L. (2010). Psychiatric symptoms and HPA axis function in adolescent methamphetamine users. J. Neuroimmune Pharmacol. 5, 582-591. doi: 10.1007/s11481-010-9206-y

Kornhuber, J., Mack-Burkhardt, F., Riederer, P., Hebenstreit, G. F., Reynolds, G. P., Andrews, H. B., et al. (1989). [3H]MK-801 binding sites in postmortem brain regions of schizophrenic patients. J. Neural Transm. 77, 231-236. doi: 10.1007/BF01248936

Kwon, D. H., Kim, B. S., Chang, H., Kim, Y. I., Jo, S. A., and Leem, Y. H. (2013). Exercise ameliorates cognition impairment due to restraint stress-induced oxidative insult and reduced BDNF level. Biochem. Biophys. Res. Commun. 434, 245-251. doi: 10.1016/j.bbrc.2013.02.111

Law, A. J., Kleinman, J. E., Weinberger, D. R., and Weickert, C. S. (2007). Diseaseassociated intronic variants in the ErbB4 gene are related to altered ErbB4 splicevariant expression in the brain in schizophrenia. Hum. Mol. Genet. 16, 129-141. doi: $10.1093 / \mathrm{hmg} / \mathrm{ddl} 449$

Law, A. J., Shannon Weickert, C., Hyde, T. M., Kleinman, J. E., and Harrison, P. J. (2004). Neuregulin-1 (NRG-1) mRNA and protein in the adult human brain. Neuroscience 127, 125-136. doi: 10.1016/j.neuroscience.2004.04.026

Lawrie, S. M., McIntosh, A. M., Hall, J., Owens, D. G., and Johnstone, E. C. (2008). Brain structure and function changes during the development of schizophrenia: the evidence from studies of subjects at increased genetic risk. Schizophr. Bull. 34, 330-340. doi: 10.1093/schbul/sbm158

Lee, P. R., Brady, D., and Koenig, J. I. (2003). Corticosterone alters N-methyl-Daspartate receptor subunit mRNA expression before puberty. Brain Res. Mol. Brain Res. 115, 55-62. doi: 10.1016/S0169-328X(03)00180-3

Lei, Y., and Tejani-Butt, S. M. (2010). N-methyl-d-aspartic acid receptors are altered by stress and alcohol in Wistar-Kyoto rat brain. Neuroscience 169, 125-131. doi: 10.1016/j.neuroscience.2010.05.003

Leussis, M. P., Lawson, K., Stone, K., and Andersen, S. L. (2008). The enduring effects of an adolescent social stressor on synaptic density, part II: poststress reversal of synaptic loss in the cortex by adinazolam and MK-801. Synapse 62, 185-192. doi: 10.1002/syn.20483

Lewis, D. A., and Levitt, P. (2002). Schizophrenia as a disorder of neurodevelopment. Annu. Rev. Neurosci. 25, 409-432. doi: 10.1146/annurev.neuro.25.112701.142754

Li, B., Woo, R. S., Mei, L., and Malinow, R. (2007). The neuregulin-1 receptor erbB4 controls glutamatergic synapse maturation and plasticity. Neuron 54, 583-597. doi: 10.1016/j.neuron.2007.03.028

Lieth, E., Lanoue, K. F., Berkich, D. A., Xu, B., Ratz, M., Taylor, C., et al. (2001). Nitrogen shuttling between neurons and glial cells during glutamate synthesis. J. Neurochem. 76, 1712-1723. doi: 10.1046/j.1471-4159.2001.00156.x

Long, L. E., Chesworth, R., Arnold, J. C., and Karl, T. (2010). A follow-up study: acute behavioural effects of Delta(9)-THC in female heterozygous neuregulin 1 transmembrane domain mutant mice. Psychopharmacology (Berl.) 211, 277-289. doi: 10.1007/s00213-010-1896-6

Long, L. E., Chesworth, R., Huang, X. F., McGregor, I. S., Arnold, J. C., and Karl, T. (2013). Transmembrane domain Nrgl mutant mice show altered susceptibility to the neurobehavioural actions of repeated THC exposure in adolescence. Int. J. Neuropsychopharmacol. 16, 163-175. doi: 10.1017/S146114571 1001854

Long, L. E., Chesworth, R., Huang, X. F., Wong, A., Spiro, A., McGregor, I. S., et al. (2012). Distinct neurobehavioural effects of cannabidiol in transmembrane domain neuregulin 1 mutant mice. PLoS ONE 7:e34129. doi: 10.1371/journal.pone.0034129

Magarinos, A. M., Li, C. J., Gal Toth, J., Bath, K. G., Jing, D., Lee, F. S., et al. (2011). Effect of brain-derived neurotrophic factor haploinsufficiency on stressinduced remodeling of hippocampal neurons. Hippocampus 21, 253-264. doi: 10.1002/hipo.20744

McDonald, J. W., and Johnston, M. V. (1990). Physiological and pathophysiological roles of excitatory amino acids during central nervous system development. Brain Res. Brain Res. Rev. 15, 41-70. doi: 10.1016/0165-0173(90)90011-C

McDougall, S. J., Widdop, R. E., and Lawrence, A. J. (2004). Medial prefrontal cortical integration of psychological stress in rats. Eur. J. Neurosci. 20, 2430-2440. doi: 10.1111/j.1460-9568.2004.03707.x
McEwen, B. S. (2007). Physiology and neurobiology of stress and adaptation: central role of the brain. Physiol. Rev. 87, 873-904. doi: 10.1152/physrev.00041.2006

Mei, L., and Xiong, W. C. (2008). Neuregulin 1 in neural development, synaptic plasticity and schizophrenia. Nat. Rev. Neurosci. 9, 437-452. doi: $10.1038 /$ nrn2392

Michelsen, K. A., Van Den Hove, D. L., Schmitz, C., Segers, O., Prickaerts, J., and Steinbusch, H. W. (2007). Prenatal stress and subsequent exposure to chronic mild stress influence dendritic spine density and morphology in the rat medial prefrontal cortex. BMC Neurosci. 8:107. doi: 10.1186/1471-2202-8-107

Murphy, S. P., and Bielby-Clarke, K. (2008). Neuregulin signaling in neurons depends on ErbB4 interaction with PSD-95. Brain Res. 1207, 32-35. doi: 10.1016/j.brainres.2008.02.063

Murray, R. M., Jones, P., and O'callaghan, E. (1991). Fetal brain development and later schizophrenia. Ciba Found. Symp. 156, 155-163. discussion: 163-170.

Myin-Germeys, I., Krabbendam, L., Delespaul, P. A., and Van Os, J. (2003). Do life events have their effect on psychosis by influencing the emotional reactivity to daily life stress? Psychol. Med. 33, 327-333. doi: 10.1017/S0033291702006785

Newell, K. A., Karl, T., and Huang, X. F. (2013). A neuregulin 1 transmembrane domain mutation causes imbalanced glutamatergic and dopaminergic receptor expression in mice. Neuroscience 248, 670-680. doi: 10.1016/j.neuroscience.2013.06.037

Newell, K. A., Zavitsanou, K., and Huang, X. F. (2005). Ionotropic glutamate receptor binding in the posterior cingulate cortex in schizophrenia patients. Neuroreport 16, 1363-1367. doi: 10.1097/01.wnr.0000174056.11403.71

Paus, T., Keshavan, M., and Giedd, J. N. (2008). Why do many psychiatric disorders emerge during adolescence? Nat. Rev. Neurosci. 9, 947-957. doi: $10.1038 / \mathrm{nrn} 2513$

Paxinos, G. F. K. B.J. (2004). The Mouse Brain in Sterotaxic Coordinates. 2nd Edn. San Diego, CA: Academic Press, Elsevier Science USA.

Pearce, I. A., Cambray-Deakin, M. A., and Burgoyne, R. D. (1987). Glutamate acting on NMDA receptors stimulates neurite outgrowth from cerebellar granule cells. FEBS Lett. 223, 143-147. doi: 10.1016/0014-5793(87)80525-2

Preston, A. R., Shohamy, D., Tamminga, C. A., and Wagner, A. D. (2005). Hippocampal function, declarative memory, and schizophrenia: anatomic and functional neuroimaging considerations. Curr. Neurol. Neurosci. Rep. 5, 249-256. doi: 10.1007/s11910-005-0067-3

Radley, J. J., Rocher, A. B., Miller, M., Janssen, W. G., Liston, C., Hof, P. R., et al. (2006). Repeated stress induces dendritic spine loss in the rat medial prefrontal cortex. Cereb. Cortex 16, 313-320. doi: 10.1093/cercor/bhi104

Radley, J. J., Rocher, A. B., Rodriguez, A., Ehlenberger, D. B., Dammann, M., McEwen, B. S., et al. (2008). Repeated stress alters dendritic spine morphology in the rat medial prefrontal cortex. J. Comp. Neurol. 507, 1141-1150. doi: $10.1002 /$ cne. 21588

Radley, J. J., Sisti, H. M., Hao, J., Rocher, A. B., McCall, T., Hof, P. R., et al. (2004). Chronic behavioral stress induces apical dendritic reorganization in pyramidal neurons of the medial prefrontal cortex. Neuroscience 125, 1-6. doi: 10.1016/j.neuroscience.2004.01.006

Rahdar, A., and Galvan, A. (2014). The cognitive and neurobiological effects of daily stress in adolescents. Neuroimage 92C, 267-273. doi: 10.1016/j.neuroimage.2014.02.007

Reul, J. M., Hesketh, S. A., Collins, A., and Mecinas, M. G. (2009). Epigenetic mechanisms in the dentate gyrus act as a molecular switch in hippocampusassociated memory formation. Epigenetics 4, 434-439. doi: 10.4161/epi.4.7.9806

Scheetz, A. J., and Constantine-Paton, M. (1994). Modulation of NMDA receptor function: implications for vertebrate neural development. FASEB J. 8, 745-752.

Sheehan, T. P., Chambers, R. A., and Russell, D. S. (2004). Regulation of affect by the lateral septum: implications for neuropsychiatry. Brain Res. Brain Res. Rev. 46, 71-117. doi: 10.1016/j.brainresrev.2004.04.009

Sircar, R. (2000). Developmental maturation of the N-methyl-D-aspartic acid receptor channel complex in postnatal rat brain. Int. J. Dev. Neurosci. 18, 121-131. doi: 10.1016/S0736-5748(99)00069-6

Spencer, J. R., Darbyshire, K. M., Boucher, A. A., and Arnold, J. C. (2012). Adolescent neuregulin 1 heterozygous mice display enhanced behavioural sensitivity to methamphetamine. Prog. Neuropsychopharmacol. Biol. Psychiatry. 39, 376-381. doi: 10.1016/j.pnpbp.2012.07.014

Spencer, J. R., Darbyshire, K. M., Boucher, A. A., Kashem, M. A., Long, L. E., McGregor, I. S., et al. (2013). Novel molecular changes induced by Nrgl hypomorphism and Nrgl-cannabinoid interaction in adolescence: 
a hippocampal proteomic study in mice. Front. Cell. Neurosci. 7:15. doi: $10.3389 /$ fncel.2013.00015

Stefani, M. R., and Moghaddam, B. (2005). Transient N-methyl-D-aspartate receptor blockade in early development causes lasting cognitive deficits relevant to schizophrenia. Biol. Psychiatry 57, 433-436. doi: 10.1016/j.biopsych.2004.11.031

Stefansson, H., Sigurdsson, E., Steinthorsdottir, V., Bjornsdottir, S., Sigmundsson, T., Ghosh, S., et al. (2002). Neuregulin 1 and susceptibility to schizophrenia. Am. J. Hum. Genet. 71, 877-892. doi: 10.1086/342734

Sterlemann, V., Rammes, G., Wolf, M., Liebl, C., Ganea, K., Muller, M. B., et al. (2010). Chronic social stress during adolescence induces cognitive impairment in aged mice. Hippocampus 20, 540-549. doi: 10.1002/hipo.20655

Sullivan, R. M., and Gratton, A. (1999). Lateralized effects of medial prefrontal cortex lesions on neuroendocrine and autonomic stress responses in rats. J. Neurosci. 19, 2834-2840.

Sutherland, J. E., Burian, L. C., Covault, J., and Conti, L. H. (2010). The effect of restraint stress on prepulse inhibition and on corticotropin-releasing factor (CRF) and CRF receptor gene expression in Wistar-Kyoto and Brown Norway rats. Pharmacol. Biochem. Behav. 97, 227-238. doi: 10.1016/j.pbb.2010.08.003

Sutherland, J. E., and Conti, L. H. (2011). Restraint stress-induced reduction in prepulse inhibition in Brown Norway rats: role of the CRF2 receptor. Neuropharmacology 60, 561-571. doi: 10.1016/j.neuropharm.2010.12.022

Taylor, S. B., Taylor, A. R., and Koenig, J. I. (2012). The interaction of disrupted Type II Neuregulin 1 and chronic adolescent stress on adult anxiety- and fear-related behaviors. Neuroscience 249, 31-42. doi: 10.1016/j.neuroscience.2012.09.045

Taylor, S. B., Taylor, A. R., Markham, J. A., Geurts, A. M., Kanaskie, B. Z., and Koenig, J. I. (2010). Disruption of the neuregulin 1 gene in the rat alters HPA axis activity and behavioral responses to environmental stimuli. Physiol. Behav. 104, 205-214. doi: 10.1016/j.physbeh.2010.11.015

Tzanoulinou, S., Riccio, O., De Boer, M. W., and Sandi, C. (2014). Peripubertal stress-induced behavioral changes are associated with altered expression of genes involved in excitation and inhibition in the amygdala. Transl. Psychiatry 4:e410. doi: 10.1038/tp.2014.54

Van Leeuwen, A. P., Creemers, H. E., Greaves-Lord, K., Verhulst, F. C., Ormel, J., and Huizink, A. C. (2011). Hypothalamic-pituitary-adrenal axis reactivity to social stress and adolescent cannabis use: the TRAILS study. Addiction 106, 1484-1492. doi: 10.1111/j.1360-0443.2011.03448.x

Van Os, J., Kenis, G., and Rutten, B. P. (2010). The environment and schizophrenia. Nature 468, 203-212. doi: 10.1038/nature09563

Van Winkel, R., Esquivel, G., Kenis, G., Wichers, M., Collip, D., Peerbooms, O., et al. (2010). REVIEW: genome-wide findings in schizophrenia and the role of geneenvironment interplay. CNS Neurosci. Ther. 16, e185-192. doi: 10.1111/j.17555949.2010.00155.x

Van Winkel, R., Stefanis, N. C., and Myin-Germeys, I. (2008). Psychosocial stress and psychosis. A review of the neurobiological mechanisms and the evidence for gene-stress interaction. Schizophr. Bull. 34, 1095-1105. doi: $10.1093 /$ schbul/sbn 101

Velakoulis, D., Pantelis, C., McGorry, P. D., Dudgeon, P., Brewer, W., Cook, M., et al. (1999). Hippocampal volume in first-episode psychoses and chronic schizophrenia: a high-resolution magnetic resonance imaging study. Arch. Gen. Psychiatry 56, 133-141. doi: 10.1001/archpsyc.56.2.133

Viviani, B., Bartesaghi, S., Gardoni, F., Vezzani, A., Behrens, M. M., Bartfai, T., et al. (2003). Interleukin-1beta enhances NMDA receptor-mediated intracellular calcium increase through activation of the Src family of kinases. J. Neurosci. 23, 8692-8700.
Viviani, B., Boraso, M., Valero, M., Gardoni, F., Marco, E. M., Llorente, R., et al. (2013). Early maternal deprivation immunologically primes hippocampal synapses by redistributing interleukin-1 receptor type I in a sex dependent manner. Brain Behav. Immun. 23, 8692-8700. doi: 10.1016/j.bbi.2013. 09.008

Viviani, B., Gardoni, F., Bartesaghi, S., Corsini, E., Facchi, A., Galli, C. L., et al. (2006). Interleukin-1 beta released by gp120 drives neural death through tyrosine phosphorylation and trafficking of NMDA receptors. J. Biol. Chem. 281, 30212-30222. doi: 10.1074/jbc.M602156200

Von Bohlen Und Halbach, O., Zacher, C., Gass, P., and Unsicker, K. (2006). Agerelated alterations in hippocampal spines and deficiencies in spatial memory in mice. J. Neurosci. Res. 83, 525-531. doi: 10.1002/jnr.20759

Walker, E., and Bollini, A. M. (2002). Pubertal neurodevelopment and the emergence of psychotic symptoms. Schizophr. Res. 54, 17-23. doi: 10.1016/S09209964(01)00347-4

Walker, E., Mittal, V., and Tessner, K. (2008). Stress and the hypothalamic pituitary adrenal axis in the developmental course of schizophrenia. Annu. Rev. Clin. Psychol. 4, 189-216. doi: 10.1146/annurev.clinpsy.4.022007.141248

Wang, C., McInnis, J., Ross-Sanchez, M., Shinnick-Gallagher, P., Wiley, J. L., and Johnson, K. M. (2001). Long-term behavioral and neurodegenerative effects of perinatal phencyclidine administration: implications for schizophrenia. Neuroscience 107, 535-550. doi: 10.1016/S0306-4522(01) 00384-0

Weinberger, D. R. (1987). Implications of normal brain development for the pathogenesis of schizophrenia. Arch. Gen. Psychiatry 44, 660-669. doi: 10.1001/archpsyc.1987.01800190080012

Weinberger, D. R., and Lipska, B. K. (1995). Cortical maldevelopment, antipsychotic drugs, and schizophrenia: a search for common ground. Schizophr. Res. 16, 87-110. doi: 10.1016/0920-9964(95)00013-C

Wenthold, R. J., Prybylowski, K., Standley, S., Sans, N., and Petralia, R. S. (2003). Trafficking of NMDA receptors. Annu. Rev. Pharmacol. Toxicol. 43, 335-358. doi: 10.1146/annurev.pharmtox.43.100901.135803

Wiley, J. L., Buhler, K. G., Lavecchia, K. L., and Johnson, K. M. (2003). Pharmacological challenge reveals long-term effects of perinatal phencyclidine on delayed spatial alternation in rats. Prog. Neuropsychopharmacol. Biol. Psychiatry 27, 867-873. doi: 10.1016/S0278-5846(03)00146-5

Conflict of Interest Statement: The authors declare that the research was conducted in the absence of any commercial or financial relationships that could be construed as a potential conflict of interest.

Received: 21 June 2014; accepted: 13 August 2014; published online: 29 September 2014.

Citation: Chohan TW, Nguyen A, Todd SM, Bennett MR, Callaghan P and Arnold JC (2014) Partial genetic deletion of neuregulin 1 and adolescent stress interact to alter NMDA receptor binding in the medial prefrontal cortex. Front. Behav. Neurosci. 8:298. doi: $10.3389 /$ fnbeh.2014.00298

This article was submitted to the journal Frontiers in Behavioral Neuroscience. Copyright (C) 2014 Chohan, Nguyen, Todd, Bennett, Callaghan and Arnold. This is an open-access article distributed under the terms of the Creative Commons Attribution License (CC BY). The use, distribution or reproduction in other forums is permitted, provided the original author(s) or licensor are credited and that the original publication in this journal is cited, in accordance with accepted academic practice. No use, distribution or reproduction is permitted which does not comply with these terms. 